\title{
PENGEMBANGAN MODEL DAYA SAING UMKM BATIK MELALUI ECS
}

\author{
Retno Dewanti; Ina Melati; Freddy Simbolon \\ Management Department, School of Business Management, BINUS University \\ Jln K.H. Syahdan No. 9, Palmerah, Jakarta Barat 11480 \\ retnodewanti@binus.edu; ina.melati.ind@binus.ac.id; freddysimbolon@binus.ac.id
}

\begin{abstract}
SMEC has high durability against any unpleasant economic conditions. Moreover, SMALL MEDIUM ENTERPRISES of batik has had the ability to produce export and derived foreign exchange for the country. It is important to continue to do the construction and development of batik industry competitiveness in order to compete in this era of free trade. The purpose of this research is to find a development Model as an integrated system capability of integrating Indonesian batik business, which is supported by the existing infrastructure so that it is capable of being one of the pre-eminent business typical batik Indonesia which has been recognized as one of the world heritage of Indonesian as a nation. Methods the study was a qualitative Method to find the organization model and hybrid formulation of e community system to support collaboration among organizations. This research has enabled independent business group supported a Hybrid organization building strength together in the era of globalization based on Electronic Community System that is driven by each component in the Hybrid Organization.
\end{abstract}

Keywords: system, electronic, community, Batik

\begin{abstract}
ABSTRAK
UMKM memiliki daya tahan tinggi terhadap kondisi ekonomi separah apapun. Apalagi UMKM batik telah memiliki kemampuan ekspor yang menghasilkan devisa Negara. Penting untuk terus melakukan pembinaan dan pengembangan daya saing industry batik agar mampu bersaing dalam era perdagangan bebas. Tujuan dari penelitian ini adalah menemukan pengembangan Model sebagai usulan sistem yang terintegrasi yang mampu memadukan bisnis batik Indonesia ditunjang infrastruktur yang ada sehingga mampu menjadi salah satu unggulan bisnis khas Indonesia yang mana batik telah diakui dunia sebagai salah satu warisan umat manusia yang dihasilkan bangsa Indonesia. Metode penelitian ini adalah metode kualitatif untuk menemukan model organisasi hybrid dan perumusan e community system untuk mendukung kolaborasi antar organisasi. Penelitian ini memampukan usaha Mandiri secara berkelompok ditunjang hybrid organization membangun kekuatan bersama di era globalisasi berdasarkan Electronic Community System yang digerakkan oleh masing-masing komponen dalam hybrid organization.
\end{abstract}

Kata kunci: system, electronic, community, Batik 


\section{PENDAHULUAN}

Sentra Bisnis Batik di Jawa sudah sedemikian tersebar menjadi andalan pendapatan daerah yang utama dan menjadi penggerak ekonomi masyarakatnya, namun sayangnya belum secara optimal memiliki kekuatan informasi yang mampu menopang berkembangnya usaha ekspor. Hal ini dibuktikan dengan temuan lapangan bahwa di sentra sentra batik di Jawa terutama Pekalongan, Yogyakarta, Solo, pada umumnya tidak didukung oleh sinergi informasi yang kuat dan hanya mengandalkan kekuatan modal usaha masing-masing sehingga pola menggalang tanggungjawab bersama untuk pelayanan ekspor belumlah sesuai dengan harapan. Kecenderungan ekspor secara tradisional dilakukan dengan menunggu pelanggan asing yang datang dan kemudian melayaninya, apabila kuota tidak tercukupi maka tidak ada solusinya. UMKM Pemerintah, koperasi, dan usaha mandiri serta komponen masyarakat lainnya seperti perguruan tinggi memiliki tanggung jawab bersama untuk menjaga dan melestarikan budaya serta mendorong UMKM untuk memampukan daya saingnya hingga ke manca negara. Batik menjadi hasil budaya bangsa yang telah diakui oleh dunia (UNESCO) dan penting bagi bangsa Indonesia untuk melestarikan warisan budaya dan mengembangkannya menjadi nilai unggulan bisnis dari Indonesia.

Hasil penelitian terdahulu, Dewanti (2010) menyatakan bahwa peran pemerintah dalam sinerginya dengan koperasi hanya mampu menggerakkan koperasi untuk membantu Usaha Mandiri dalam mendistribusikan batik saja. Sedangkan peran koperasi untuk informasi dan inovasi belumlah signifikan. Peran koperasi saat ini hanya berfungsi sebagai distributor yang memperlancar proses penyaluran batik ke pelanggan. Citra koperasi yang melemah di sentra bisnis batik sudah selayaknya menjadi prioritas Pemda untuk diberdayakan sesuai dengan fungsinya yakni menjadi soko guru pengembangan usaha. Sesungguhnya koperasi bukanlah pengecer semata namun dapat dimanfaatkan menjadi pusat penggerak dan pengembang usaha di sentranya. Peran koperasi bukanlah semata sebagai badan usaha, namun manifestasi ideologi ekonomi atas dasar nilai-nilai swadaya, swatanggung jawab, persamaan, keadilan, dan kesetiakawanan. Oleh karenanya, koperasi harus mampu memperbaiki citranya sebagai kumpulan golongan ekonomi lemah pemburu fasilitas dan menghapus citra lemahnya dalam kegiatan usaha serta minimnya gotong-royong.

Teknologi informasi dan komunikasi berupa sumber daya informasi yang saling terkoneksi dalam satu kontrol manajemen langsung yang sama dan memiliki pembagian wewenang fungsi yang terpadu, membentuk sebuah sistem yang terdiri dari hardware, software, informasi, data, aplikasi, komunikasi, dan manusia. Selanjutnya Turban dan Aronson menjelaskan bahwa perusahaan yang dibantu aktifitasnya dengan teknologi informasi seperti keuangan, sumber daya manusia, pemeliharaan dan pemasaran dapat bekerja lebih efektif dan efisien dibandingkan ketika belum memanfaatkan teknologi informasi.

Organisasi masa kini memiliki tanggung jawab yang berorientasi sosial. Untuk itu, perlu dikelola dan dilakukan pembinaan secara optimal melalui sinergi bisnis yang saling menunjang dan mampu mendorong UMKM agar terus bertahan dan meningkatkan daya saingnya. Model sinergi yang didasari oleh sistem terintegrasi akan dapat memacu percepatan proses informasi dan memupuk kebersamaan menggalang kekuatan bangsa untuk memperjuangkan ekonomi rakyat. Setyabudi (paketrupiah.com) menegaskan bahwa Solo menghasilkan kain batik dalam jumlah yang banyak (6000 detail motif khas). Kampung kauman Surakarta terdiri atas 20-30 home industry menjadi langganan para wisatawan Jepang, Eropa, Asia Tenggara, dan Amerika Serikat, sedangkan laweyan sebagai "juragan batik" terkenal dari tahun 1970 (surakarta.go.id). Mutu batik ditentukan oleh iklim dan keberadaan usaha setempat, faktor sejarah, perdagangan, dan kesiapan masyarakatnya dalam menerima paham serta pemikiran baru (batikmarkets.com). Pendayagunaan sistem informasi menjadi pendukung utama untuk percepatan usaha dan perluasan jangkauan pemasaran ekspor, namun hal ini tergantung dari kapabilitas komunitas pengusaha batik itu sendiri untuk menerima tantangan ke depan. 


\section{METODE PENELITIAN}

Metode Kualitatif yang dilakukan bertahap terdiri dari: 1) teknik pengumpulan data menggunakan participant observation (peran serta) dan in depth interview (wawancara mendalam) kepada perwakilan sentra di Solo. Penelitian kualitatif bersifat holistik dan lebih menekankan pada proses. 2) Stainback (2003) menekankan ciri kualitatif pada partisipasi intensif, rekaman, dan penulisan serta proses dokumentasi secara bertahap dan analisis secara hati-hati dari dokumentasi yang ada serta laporan atas interpretasi suatu objek dan kedalaman interview. Dokumentasi dan seluruh partisipasi dalam riset ini direkam dalam bentuk tulisan dan gambar. Gambar berikut menunjukkan kerangka pemikiran dalam penelitian ini.

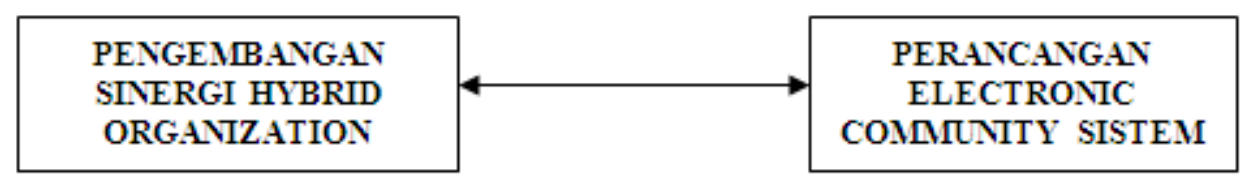

Gambar 1 Kerangka Pemikiran

\section{Ruang Lingkup Penelitian}

Lingkup penelitian ini adalah situasi mikro pasar batik PGS (Pasar Grosir Solo), Sentra Batik Kauman, dan Laweyan. Lokasi Kota Solo terpilih berdasarkan hasil riset sebelumnya yang menunjukkan keberhasilan dalam pendistribusian dan kekuatan sumber daya adalah UMKM Batik Solo dibandingkan Pekalongan dan Yogyakarta. Solo menjadi role model untuk riset lanjutan. Penelitian UMKM batik di Solo menggunakan metode kualitatif dengan melakukan verivikasi atas temuan data dan memastikan kebenaran data. Penentuan sumber data dilakukan secara purposif, yaitu dipilih dengan pertimbangan sebagai salah satu penentu pengambilan keputusan di masing-masing sentra dengan tujuan dapat menggali situasi sosial yang sesungguhnya terjadi di sentra tersebut. Adapun pengembangan peserta berdasarkan snowball sampling melibatkan rujukan mitra kerja masing-masing yang telah ditunjuk.

\section{Teknik Pengumpulan Data}

Teknik pengumpulan data adalah observasi (pengamatan) atas perilaku pengusaha batik dan memaknainya dengan turut serta partisipatif mengurai pengalaman menjual sehingga mengetahui suka dan dukanya. Partisipasi moderat dalam arti bahwa peneliti melakukan observasi partisipatif dalam beberapa kegiatan tetapi tidak semuanya. Observasi dilakukan pada 3 komponen yakni tempat, pelaku, dan aktivitas. Observasi di PGS secara purposive terpilih Zen Jufry dengan perusahaan batik printing/handmade yang berpusat di PGS. Di sentra kauman terpilih Gunawan dengan perusahaan Batik Gunawan Setiawan. Di sentra batik laweyan terpilih Perusahaan Putra Bengawan.

Kedua, interview (wawancara); peneliti mempersiapkan wawancara tak terstruktur. Pedoman wawancara hanya berupa garis besar permasalahan yang ditanyakan, terbatas pada pengalaman, pendapat, perasaan, pengetahuan, dan pencapaian indra narasumber untuk mendengarkan, mengikuti pameran. Pertanyaan dikembangkan dengan hipotesis, mempersoalkan ideal suatu situasi, menantang informan untuk merespons hipotesis alternatif, mengajak memberikan interpretasi atas sesuatu, meminta memberikan saran, meminta memberikan suatu alasan, mengungkap argumentasi tentang sesuatu, meminta data tambahan terhadap orang yang lebih tahu, mengungkap kepercayaan atas sesuatu, dan meminta informan memberikan informasi tambahan yang mengarahkan perilaku tertentu. 


\section{HASIL DAN PEMBAHASAN}

\section{Model Hybrid Organization: Kajian Usaha Mandiri}

Usaha mandiri dimaksud adalah usaha yang didirikan oleh bagian dari masyarakat itu sendiri dalam merencanakan usaha dan mengimplementasikan usahanya dengan modal pribadi maupun kelompok yang bertujuan untuk memperbaiki ekonomi (Man, dkk., 2002). Usaha mandiri yang mampu bertahan adalah usaha mandiri yang mampu mengembangkan usahanya dan proaktif terhadap perubahan lingkungan. Namun tidak semua usaha mandiri mampu berhasil dalam menjawab tantangan. Chittor dan Das (2007) menegaskan bahwa kegagalan usaha terletak pada relationship. Hal ini menunjukkan bahwa usaha mandiri diharapkan mampu membina hubungan dengan pemangku kepentingan yang lainnya. Wilkinson dan Skykes (2010) dalam risetnya tentang Australian Government memberikan petunjuk bahwa fasilitator dan relationship sangat penting dalam mengembangkan usaha. Scott-ladd dan Noonan (2012) dalam presentasinya di seminar Forum Manajemen Indonesia di Yogyakarta menyebutkan pentingnya komunitas usaha membina relationship. Nelson, dkk (2010) berargumentasi bahwa sukses bisnis bergantung pada kemampuan mengakses informasi demi meningkatkan pengetahuan pebisnis melalui pendekatan workshop keahlian, pengalaman yang dibutuhkannya. Pernyataan ini menimbulkan pemikiran bahwa penting dibentuk komunitas para pengusaha batik sebagai wadah untuk berbagi ilmu dan pengalaman serta informasi pengembangan usaha.

Sesungguhnya Pasar batik Solo menerima banyak order ekspor, namun tidak tercukupi karena kurangnya sumber daya manusia untuk mengerjakannya. Padahal, hal ini bisa tercukupi bila terjadi komunikasi intensif dalam jaringan kerjasama asosiasi batik. Contohnya, order yang datang pada 2008 ke pabrik Zen hanya terpenuhi sebesar $40 \%$. Kendala yang ada adalah kurangnya SDM dan minimnya kepercayaan terhadap pengusaha lain untuk memenuhi target permintaan ekspor sesuai dengan kuantitas dan kualitas yang diinginkan. Kenyataan ini memberikan konfirmasi hasil penelitian sebelumnya bahwa kelemahan usaha mandiri terletak pada kurangnya SDM dalam proses produksi. Pendidikan SDM di Solo mayoritas SMA, sejalan dengan riset sebelumnya dan mengonfirmasi temuan riset rata-rata pendidikan karyawan UMKM di jawa 80\% mayoritas lulusan SMA (penelitian ISEI 2010 dalam sidang pleno ISEI XIV tentang revitalisasi UMKM untuk menggerakkan perekonomian nasional, 20 Juli 2010). Ini menunjukkan minimnya keahlian, dan perlu didukung oleh sinergi komunitas yang mampu meningkatkan keahlian mereka.

Masing-masing usaha berdiri sendiri dan kurangnya kerjasama satu dengan yang lain dalam menghadapi ekspor. Saat ini kerjasama yang ada hanya sebatas lingkup paguyuban, dan paguyuban ini terbatas pada kekuatan usaha yang masih minim produksi. Kebanyakan pengusaha kecil memilih usaha pendistribusian dan sekali waktu membuat batik tulis serta memproduksi barang jadi secara terbatas untuk penjualan pribadi. Pemasaran batik di Solo sudah lebih baik, hal ini dibuktikan dengan pergantian produk yang dipajang yang tidak lama, misalnya 1 tipe akan bertahan rata-rata paling lama 3 bulan. Rata-rata produksi batik tulis per tahun masing-masing toko sekitar 5-7 lembar, karena 1 lembar membutuhkan proses 3 bulan dan biasanya hanya memiliki 2 orang pembatik tradisional. Banyak toko penjualan batik memperlihatkan campuran produk yakni memasarkan produk orang lain, memasarkan produk sendiri, dan memasarkan batik tulis gabungan produk sendiri dan tampungan hasil pembatik tradisional.

Kenyataan riset menunjukkan bahwa usaha mandiri masih minim pengembangan usaha. Sehingga apabila ada pesanan untuk ekspor, kelabakan untuk memenuhinya dan akan hilang begitu saja orderan tersebut karena sebatas kuota yang bisa dipenuhi. Relationship yang baik antarpengusaha batik memerlukan kepercayaan dan aktivitas intensif untuk mempelajari pengalaman dan pengetahuan masing-masing usaha. Saat ini dukungan berbagi pengalaman antar pengusaha batik sangatlah minim. 
Padahal temuan riset sebelumnya menunjukkan bahwa keunggulan usaha mandiri terletak pada teknologi, yang berarti bahwa pengusaha batik sangatlah aktif merespons teknologi dengan baik. Peluang ini menjadikan teknologi adalah fasilitas penting yang disadari oleh pengusaha batik. Teknologi informasi di Solo bukanlah hal yang baru, terbukti Jokowi saat menjadi walikota Solo telah berhasil melakukan pembenahan sistem informasi. Pengusaha batik di Solo banyak yang memanfaatkan website untuk pemasaran merek usahanya namun website masing-masing usaha batik berfungsi dalam e-marketing saja. Untuk itu, sangat penting dibentuk sinergi bersama dalam Electronic Community System yang melibatkan seluruh unsur dalam wilayah domisili pengusaha batik dan tidak menutup kemungkinan untuk menjadi role model bagi daerah lainnya.

Peran pengusaha batik dalam e-community adalah berbagi pengalaman dalam promosi produk dan jasa serta keahlian, dan berbagi rejeki dalam merespons permintaan ekspor dengan mengaktifkan koperasi sebagai entitas sentra bisnis menjadi admin yang memperantarai gotong-royong antarpengusaha, dan unsur lainnya. Forum komunitas dapat dimanfaatkan untuk menyampaikan segala keluhan ataupun masalah terkait dengan pengembangan usaha yang akan direspons oleh sinergi yang ada yakni pemerintah daerah, perguruan tinggi, dan juga koperasi serta unsur lainnya. Kemudahan Komunikasi ini dapat mengatasi keterbatasan waktu para pengusaha dalam konsultasi dan pertemuan fisik dengan pemerintah, koperasi atau lembaga lainnya. Rayport dan Jaworski (2003), Turban (2004) menguatkan pendapat bahwa e-commerce bermanfaat dalam kolaborasi dan komunikasi dengan dimediasi oleh teknologi informasi. Temuan riset ISEI (2010) membenarkan bahwa penggunaan teknologi informasi dan akses informasi oleh UMKM di Jawa tertinggi dibandingkan UMKM daerah lainnya. Ini menunjukkan ketepatan objek riset di Solo dalam penggunaan IT oleh UMKM Batik.

\section{Model Hybrid Organization: Kajian Pemerintah Daerah}

Dalam riset sebelumnya, Dewanti (2010), kelemahan Pemda adalah pendanaan. Dalam pendanaan diperlukan sinergi antara Pemda dengan BRI, karena berdasarkan riset ISEI (2010) bahwa UMKM mayoritas menjadikan BRI sebagai rujukan pendanaan tertinggi. Keunggulan Pemda dalam kemitraan dapat menjadi kekuatan dasar membangun jaringan kerjasama yang baik antarinstansi. Hanya BRI yang memanfaatkan kebijakan hapus-tagih melalui peraturan Menteri Keuangan 64 tahun 2010. Pemda juga seharusnya proaktif untuk mengatasi masalah-masalah pendanaan dengan kementerian keuangan dalam mengatasi piutang instansi pemerintah, khsusnya piutang terhadap Usaha Mikro, Kecil, dan Menengah (UMKM). Dalam sinergi UMKM batik, sebaiknya pemerintah melibatkan BRI sebagai lembaga perbankan yang mampu mengevaluasi proses pendanaan dan mengatasi kemacetan kredit dan penghapusan tagihan. Sinergi ini menjadi kebutuhan pokok bagi pertumbuhan UMKM. Berdasarkan riset ISEI (2010), dibuktikan regresi pembiayaan usaha secara signifikan dan positif berpengaruh terhadap pengembangan usaha. Untuk itu diperlukan skema pembayaan yang sesuai dengan perkembangan UMKM daerah dan diperlukan dukungan pola jaminan pinjaman perbankan karena pada kenyataannya, dari temuan di lapangan, perbankan masih mewajibkan para pengusaha menjaminkan sertifikat tanah/rumah pada saat mengajukan pembiayaan usaha.

Koordinasi antara Pemda dan Menko Perekonomian dalam inovasi skema bantuan pembiayaan dan evaluasi pendanaan sangat dipentingkan. Hasil Kebijakan Pemda dalam koordinasi dengan beberapa unsur pendukung usaha perlu disosialisasikan secara berkelanjutan sehingga tidak lagi terjadi gap informasi antara pengusaha dengan update informasi Pemda. Misalnya, mengenai kebijakan fiskal dan nonfiskal. Pemda juga berperan dalam melindungi UMKM daerahnya terutama hak paten produk dan desain batik, untuk itu diperlukan kemudahan proteksi dan kecepatan informasi dalam merespons inovasi UMKM di daerahnya. Komunitas Asosiasi batik juga dapat memanfaatkan bundling produk di antara anggota komunitas itu sendiri (Levent, 2005). Berarti, sinergi beberapa instansi yang terlibat dapat saling mendukung dalam mencapai tujuan bersama meningkatkan ekonomi. ECS dapat dimanfaatkan untuk pengelolaan informasi usaha, informasi sarana dan prasarana, perizinan, peluang usaha, dan promosi dagang secara terus-menerus oleh Pemda dan 
jaringannya. Melalui sinergi ECS, secara cepat Pemda juga dapat merespons tanya-jawab melalui forum promosi sehingga memudahkan jaringan informasi untuk membantu mengembangkan usaha.

\section{Model Hybrid Organization: Kajian Koperasi}

Dari kompas.com (12 Juli 2012), perayaan hari koperasi nasional di Palangkaraya mendeklarasikan nota kesepahaman antara Asosiasi Pengusaha Retail Indonesia (Aprindo) serta Dewan Koperasi Indonesia (Dekopin) dengan Koperasi Angkasa Malaysia. Deklarasi ini menunjukkan adanya sinergi yang dibangun bersama demi menjaga eksistensi koperasi. Dukungan ini sudah seharusnya meningkatkan kinerja keaktifan Rapat Anggota/kelembagaan koperasi, meningkatkan aktivasi praktik koperasi yang jujur, menjadi pendorong sifat kepemimpinan yang amanah, dan memotivasi produktivitas koperasi untuk lebih baik lagi melalui gotong royong. "Asas kekeluargaan itu adalah kooperasi. Hubungan antara anggota-anggota kooperasi harus mencerminkan orang-orang bersaudara, satu keluarga,” kata Wapres mengutip Bung Hatta dalam kesempatan pidato hari jadi ke65 koperasi, 12 Juli 2012. Pernyataan ini menunjukkan bahwa tekad koperasi membentuk kekeluargaan sama halnya dengan family business.

Hanani (2012) dalam seminar nasional FMI menunjukkan bahwa family business bangkrut pada generasi ke-3. Risiko yang dialami oleh koperasi masa generasi ke-3 setelah Bung Hatta 1977 menjadi nyata, bahwa koperasi mengalami penurunan dan hal ini disadari oleh kementerian UMKM dan koperasi untuk membangkitkan kembali semangat bung Hatta mengacu pada UUD 1945 pasal 33 ayat 1 bahwa perekonomian disusun sebagai usaha bersama berdasar atas asas kekeluargaan. Semangat ini harus tetap terjaga, dan profesionalisme harus tetap ditingkatkan. Menurut Sekarbumi (2012) dalam family busines professionalism menyatakan bahwa ciri-ciri profesional adalah altruistik dan akuntabilitas yang pengertiannya adalah adanya pemahaman akan kesejahteraan orang lain dan memiliki rasa penuh tanggung jawab dan andal dalam bekerja. Ketangguhan koperasi hingga kini memperlihatkan keunggulannya, meskipun hanya berperan dalam membantu anggotanya mendistribusikan produk saja. Tidak menutup kemungkinan faktor lain yang menjadi kekuatan koperasi dapat ditingkatkan melalui pencangkokan terhadap organisasi lain seperti asosiasi ritel akan dapat mengaktifan Rapat Anggota/kelembagaan koperasi, memacu semangat praktik koperasi dan mendorong produktivitas dan kepemimpinan yang andal.

Tuntutan profesional sudah selayaknya dimiliki oleh pegawai koperasi. Saat ini, koperasi sudah lebih dimudahkan dengan bantuan manajemen software dalam mengelola manajemen, misalnya aplikasi e-koperasi, Software Koperasi Simpan Pinjam, Software Tatakelola Manajemen Koperasi (softwareksp.primasolusi.net). Keberadaan software ini menunjukkan bahwa pengelola koperasi sekarang ini diberikan kemudahan dan dituntut untuk memiliki keahlian di bidang teknologi computer terutama pemanfaatan software untuk mempercepat kinerjanya. Peran koperasi saat ini dapat secara optimal difungsikan dalam menjembatani teknologi informasi dan pemberdayaan UMKM dalam diseminasi informasi di sentra sentra batik. Keahlian ini menunjukkan bahwa sudah selayaknya koperasi diberdayakan untuk memacu percepatan arus informasi antarpengusaha sehingga terjadi sinergi family business yang didukung oleh Hybrid Organization yang tangguh yakni Pemda dan jaringannya termasuk Perguruan Tinggi. Perguruan tinggi dalam hal ini memiliki tugas pokok selain pengajaran tentunya adalah pengabdian kepada masyarakat, oleh karenanya menjadi tanggung jawab perguruan tinggi, terutama Binus University, yang memiliki kekuatan unggulan IT mengambil peran dalam sinergi kekuatan aliansi asosiasi pengusaha batik. Diharapkan sinergi ini mampu mendukung menggerakkan koperasi dalam perannya menggiatkan usaha sentra bisnis di lingkungannya.

\section{Model Hybrid Organization: Kajian Informasi}

Berdasarkan data pengguna internet 2008, 55 juta penduduk Indonesia adalah pengguna internet. Ini berarti bahwa penduduk Indonesia sangat merespons teknologi informasi. O’Brien (2005:264) mengungkapkan penggunaan bisnis dari internet telah meluas dari pertukaran informasi secara elektronik ke aplikasi strategi bisnis. Argumentasi ini menunjukkan bahwa internet tidak hanya 
berfungsi dalam pertukaran informasi, tetapi juga menjadi strategi bisnis untuk menggalang aliansi komunitas usaha sehingga mampu menghadang gelombang masuknya usaha asing ke Indonesia. Komunitas usaha dapat memanfaatkan ECS untuk membangun pola komunikasi yang secara terusmenerus menjadi jembatan informasi yang menguatkan bisnis dari terpaan persaingan usaha terhadap masuknya produk asing dan menjadi pendorong penggiat usaha untuk devisa dengan ekspor produk batik Indonesia. Kelebihan utama internet adalah kecepatan, para manajer mampu membuat keputusan dengan informasi yang lebih baik dengan waktu yang jauh lebih cepat daripada sebelumnya (Heizer dan Render, 2008:38).

O’Brien (2005:5) menyatakan bahwa sistem informasi dapat merupakan kombinasi dari orangorang, perangkat keras, perangkat lunak, jaringan komunikasi, dan sumber daya data yang mengumpulkan, mengubah, dan menyebarkan informasi dalam sebuah organisasi. Sistem informasi yang ada pada pengusaha batik di Solo saat ini cenderung unggul di informasi produk saja yang berarti bahwa e-marketing sudah mampu menjembatani informasi updating produk. Namun dalam hal penyediaan informasi tentang pelanggan dan tren ke depannya serta cara menjalin hubungan dengan pelanggan masih menemui kesulitan. Para pengusaha batik mengharapkan adanya informasi berdasarkan riset tentang perilaku konsumen batik ke depan dan keinginan untuk memperoleh latihan dalam mempertahankan hubungan dengan pelanggannya dan demi tujuan ini diperlukan teknologi informasi. Electronic Community System akan membantu merealisasikan kebutuhan ini dengan nyata atas peran Binus university dan sinergi dengan organisasi hybrid lainnya. Gambar berikut menunjukkan alur model hybrid organization pendukung usaha batik di Solo.

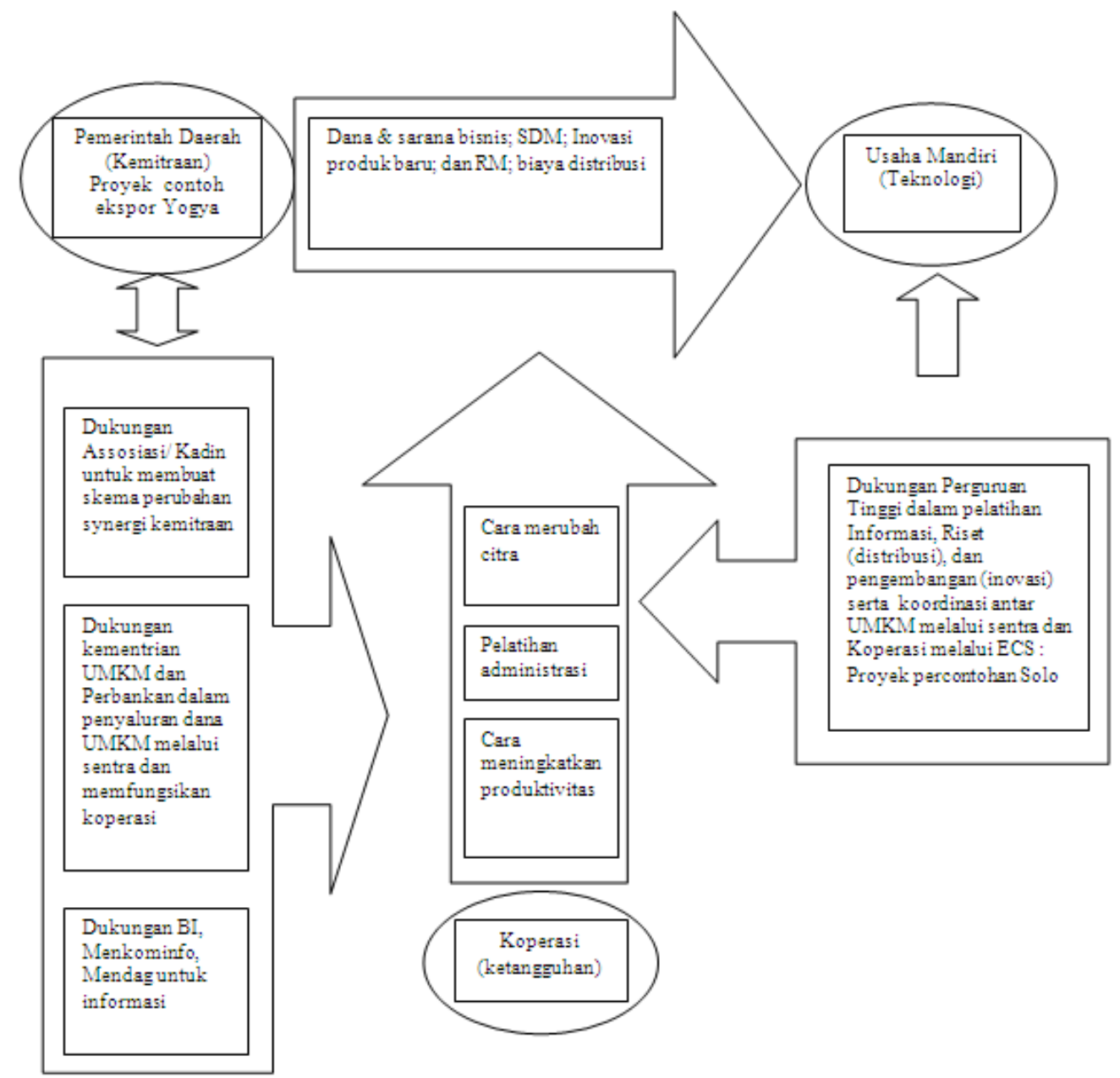

Gambar 2 Model Hybrid Organization Pendukung Usaha Batik di Solo 


\section{Rancangan Electronic Community System: Gambaran Peta Situs}

Diagram berikut menunjukkan gambaran peta situs web Asosiasi Pengusaha Batik Solo.

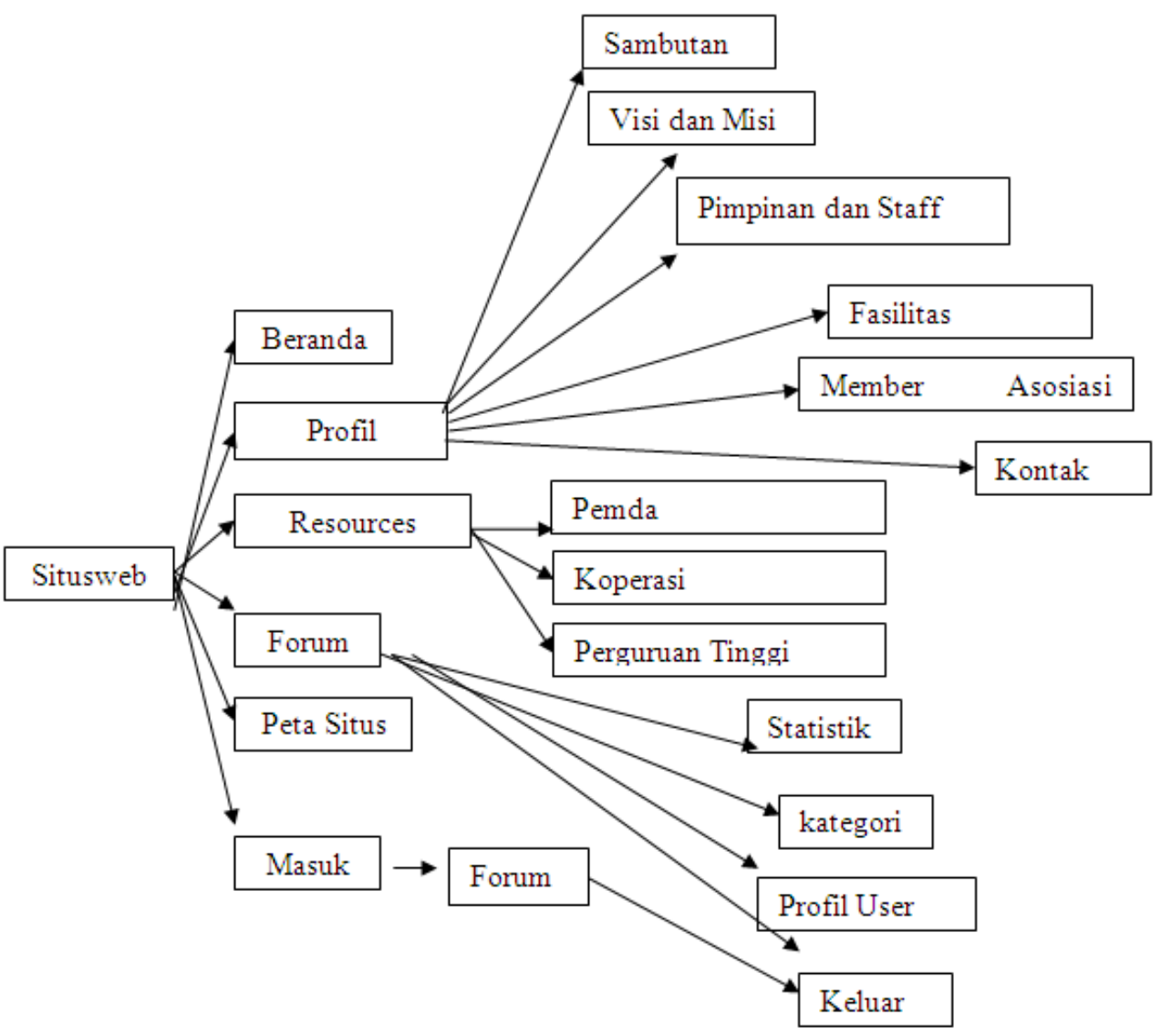

Gambar 3 Peta situs web

(Sumber: Penulis, 2012)

\section{Perancangan User Interface}

Berikut ini adalah rancangan user interface yang penulis usulkan untuk Pengembangan $e$ community pada situs web Asosiasi Pengusaha Batik Solo:

\section{Tampilan user sebelum melakukan login}

Sebelum user melakukan login, menu halaman web akan menampilkan halaman beranda, profil Asosiasi, Resources, Forum, dan Peta situs. User hanya dapat mengakses forum jika sudah melakukan login terlebih dahulu. Berikut adalah tampilan-tampilan sebelum login.

\section{Tampilan forum sebelum login}

Forum hanya dapat diakses ketika user sudah melakukan login terlebih dahulu. Pada tampilan sebelum login, user tidak dipekenankan melihat isi forum. 


\section{Tampilan Beranda}

Pada tampilan beranda, selain terdapat menu profil Asosiasi pengusaha Batik Solo, Resources, forum yang hanya dapat diakses ketika user telah melakukan login dan peta situs terdapat juga tampilan login form, lambang batik, keterangan pengunjung aktif, waktu, gambar tampilan Kota Solo dan penghargaan batik oleh UNESCO.

\section{Tampilan Profil Asosiasi}

Pada profil asosiasi terdapat sub 6 submenu, di antaranya adalah sambutan, visi dan misi, pimpinan dan staf, fasilitas, anggota asosiasi dan kontak.

\section{Sambutan}

Tampilan sambutan yang berada di halaman asosiasi, berisi tentang kata-kata yang diberikan dari Ketua asosiasi mengenai gambaran guna berdirinya Assosiasi pengusaha Batik Solo.

\section{Visi dan Misi}

Pada tampilan visi dan misi pada profil asosiasi, user dapat melihat visi dan misi serta tujuan Asosiasi pengusaha Batik Solo.

\section{Pimpinan dan Staf}

Solo.

Pada tampilan ini user dapat melihat susunan organisasi yang ada di Asosiasi Pengusaha batik

\section{Fasilitas} Batik Solo.

Pada tampilan fasilitas, user dapat mengetahui fasilitas yang terdapat di Asosiasi Pengusaha

\section{Anggota Asosiasi}

Pada tampilan member asosiasi, user dapat melihat keanggotaan seluruh anggota asosiasi.

\section{Kontak}

Pada tampilan ini user dapat mengetahui info Asosiasi pengusaha batik Solo yang dilengkapi dengan alamat surat menyurat, nomor telepon, e-mail, dan juga nama ketua.

\section{Resources}

Pada tampilan Resources terdapat tiga submenu yaitu Pemda, Perguruan Tinggi, Koperasi.

\section{Pemda}

Pada tampilan ini, user dapat melihat dan mengunduh formulir terkait pengembangan usaha yang disediakan oleh Pemda.

\section{Koperasi}

Pada tampilan ini, user dapat melihat update informasi komunitas sentra batik Solo karena Koperasi dapat menjadi admin utama yang menghubungkan banyak sinergi organisasi yang terlibat dalam organisasi serta keputusan-keputusannya. 


\section{Peta Situs}

dicari.

Pada tampilan peta situs ini, user dapat melakukan pencarian dengan cepat ke halaman yang

\section{Tampilan user setelah melakukan login di Forum}

Setelah user melakukan login, user dihadapkan pada tampilan forum. Di dalam tampilan forum tersebut terdapat statistik, kategori, profil user, dan keluar.

\section{Tampilan Statistik}

Pada tampilan forum statistik, terdapat nama user, aktivitas terakhir (fungsinya untuk informasi kegiatan akhir user lakukan dalam mem-posting ), posting terakhir (berfungsi untuk informasi posting terakhir yang user lakukan ), posting terakhir (berfungsi untuk mengetahui jumlah posting-an yang sudah user lakukan), lihat posting terakhir (berfungsi sebagai link untuk langsung ke halaman user terakhir kali mem-posting), dan temukan yang semua saya posting (berfungsi untuk melihat seluruh postingan topik user).

\section{Tampilan Kategori}

Pada tampilan forum kategori ini terdapat tiga kategori forum, peraturan forum (berisi tentang peraturan forum, berita dan event asosiasi, dan saran kritik ), forum asosiasi (terbagi lagi atas 3 kategori berdasarkan kelas yang berisi tentang Sentra laweyan, PGS, dan Kauman; kategori ini bisa ditambah lagi disesuaikan dengan jumlah sentra), dan serba-serbi Asosiasi (berisi tentang macammacam bahasan seputar asosiasi).

\section{Tampilan Profil User}

Pada tampilan profil user terdapat data personal user yang terdiri dari nama, jenis kelamin, status (berisi tentang keterangan nomor keanggotaan, terkait dengan sentra masing-masing), tanggal registrasi (yang berisi tentang keterangan user terdaftar diasosiasi ), dan e-mail.

\section{SIMPULAN}

Diperlukan sinergi yang baik antara Pemda Solo, Koperasi Sentra atau paguyuban, dan para pengusaha batik didorong oleh kekuatan yang ada yang merupakan pencangkokan paguyuban/koperasi kepada Pebisnis besar atau instansi sehingga mampu untuk terus melakukan evaluasi dalam menggerakkan usaha batik untuk ekspor dan menggalang kekuatan besar untuk menjadikan batik sebagai warisan budaya milik bersama untuk direspons secara bersama dan dapat menjadikan batik sebagai kebanggaan produk ekspor.

Pemda Solo sebaiknya berperan dalam update informasi atas informasi terkini dari pemerintah pusat, perbankan, atau instansi lain yang terkait, sedangkan Koperasi bertugas untuk menjadi admin yang menjembatani Pemda, organisasi Hybrid, perguruan tinggi, serta anggota asosiasi pengusaha batik solo. Sedangkan Peran Perguruan Tinggi adalah melakukan riset berkelanjutan untuk membangun model baru untuk menggerakkan dan mengembangkan inovasi serta distribusi dan informasi kepada para komunitas pengusaha batik. Peran Organisasi Hybrid adalah mengupayakan Program CSR (Corporate Social Responsibility) di perusahaannya untuk bertindak nyata mengentaskan pengusaha lemah dan membangun jaringan gurita di wilayah sebagai perwujudan pengabdian organisasi itu sendiri terhadap perkembangan ekonomi di wilayahnya. 
Perancangan Electronic Community System diharapkan dapat menjadi narasumber utama dalam menggeliatkan ekonomi batik terutama merespons permintaan ekspor yang dapat dilakukan bersama seluruh komunitas untuk mencukupi kuota ekspor dan menggalang kekuatan mendapatkan Devisa serta menjadi forum yang andal untuk menampung aspirasi seluruh aspek jaringan informasi yang selayaknya diperoleh oleh semua pengusaha batik.

\section{DAFTAR PUSTAKA}

Ahmad, M. (2007). Pembangunan Berkelanjutan Refleksi Singkat dan Langkah Ke Depan. Balikpapan: ISEI.

Aswicahyono, H. (2007). Membangun Daya Saing Industri. Balikpapan: ISEI.

Bachrudin, A., dan Tobing, L. H. (2003). Analisis Data Untuk Penelitian Survei. Bandung: Universitas Padjadjaran.

Bruton, G. D., White, M. A. (2006). The management of Technology and Innovation: A Strategic Approach. Thomson.

Chaundhury, Abhijit, Kuilboer, Jean-Pierre (2002). E-business and E-commerce Infrastructure: Technologies Supporting the E-business Initiative. USA: McGraw-Hill.

Chittor, R and Das, R. (2007). Professionalization of Management and Succession performance-a vital linkage, Family Business Review, Vol.20 No 1. Pp 65-79.

Dewanti, R. (2008). Kewirausahaan. Jakarta: Mitra Wacana Media.

Dewanti, R. (2010). Membangun Daya Saing Potensi Daerah Melalui UKM, laporan riset 2010. Jakarta: Binus University.

Greenstein, Marilyn, Feinman, T, M. (2000). Electronic Commerce: Security, Risk Management and Control. International Edition. McGraw-Hill.

Haag, S., Cummings, M., McCubrey, D. J. (2005). Management information systems for the information age. NY: McGraw-Hill/Irwin.

Hanani, D, A. (2012). Family Business Realities in The Global Market, slide seminar FMI 13 November 2012, di Yogyakarta.

Heizer, J., dan Render. (2008). Operation Management. Jilid 2. Jakarta: Salemba Empat.

Jurnal Ekonomi \& Kemasyarakatan. (2005). Entrepreneurship Keluar dari Jeratan Bangsa Kuli. Equilibrium Vol 2. Jakarta.

Karimi, S. (2007). Reformasi Pelayanan Publik Untuk Penguatan Pembangunan Ekonomi. Balikpapan:ISEI

Kotler, P., Armstrong, G. (2004). Principles of Marketing, Tenth Edition. New Jersey: Pearson Prentice Hall. 
Kuncoro, M. (2003). Metode Riset Untuk Bisnis \& Ekonomi. Jakarta: Erlangga.

Levent V, Orman, (2005), Design and Implementation of Electronic Communities, ( ON LINE),http://proquest.umi.com/pqdweb?index $=33 \&$ did $=835474341 \&$ SrchMode $=1 \&$ sid $=2 \& \mathrm{~F}$

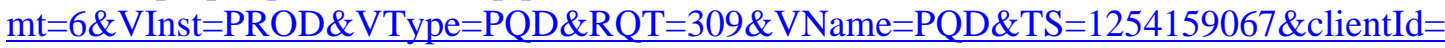
68814, 16 April 2010.

Man, T.W.Y., lau, T, and chan, K. F. (2002). the Competitiveness of Small and medium enterprises: A conceptualization with focus on entrepreneurial competences. Journal of business Venturing 17 (2): 123-142.

Marsuki. (2005). Analisis Perekonomian Nasional \& Internasional. Jakarta. Mitra Wacana Media.

Mathiassen, Lars, et.al. (2000). Object Oriented Analysis \& Design. Amerika. Aps., Denmark: Marko Publishing Prentice Hall.

Mcleod, R, Jr., Schell, G. (2001). Management Information Systems. London: Prentice Hall.

O`Brien, J. A. (2005). Introduction to Information Systems. (12 ${ }^{\text {th }}$ Edition). USA: McGraw-Hill.

Pasaribu, B. (2007). Perubahan Paradigma Perekonomian. Balikpapan: ISEI.

Peter, J. P., dan Olson, J. C. (2003). Consumer Behavior and Marketing Strategy. Sixth Edition. New York: McGraw-Hill.

Porter, M. E.(2007). Strategi Bersaing. Ed.Revisi. Tangerang: Karisma Publishing Group.

Raffles, T. S. (2008). The History of Java. Jakarta: Buku Kita.

Rayport, J. F., Jaworski, B. J. (2003). Introduction to E-Commerce. Second Edition. Mc Graw - Hill Education (Asia).

Rusli, A. (Februari, 2010). E-community System Towards First Class Mentality Development: An Infrastructure Requirements Analysis, (ON LINE), ccsenet.org/journal/index.php/cis/article/view/5128/4311, 16 April 2010.

Scoot-ladd, B., and Noonan, J. (2012). Succession planning in family farm Business; Forum Manajemen Indonesia, 13 November 2012 Yogyakarta.

Sekarbumi, A. (2012). Family Business Professionalism: presentasi paper dalam Forum Manajemen Indonesia 13 November 2012 di Yogyakarta.

Seminar Proceeding. (2007). Inovasi Menghadapi Perubahan Lingkungan Bisnis. Jakarta: Trisakti.

Sidang pleno ISEI XIV; Balikpapan 20-22 Juli 2010 ; Revitalisasi UMKM untuk menggerakkan Perekonomian Nasional.

Shneiderman, B. (2005). Designing the User Interface: Strategies for Effective Human-Computer Interaction. 4th Edition. New York: Addison-Wesley.

Shukla, T. (2010). Factors Affecting 'Internet Marketing' Campaigns with Reference to Viral and Permission Marketing. IUP Journal of Management Research. Hyderabad, vol 9(1):26. 
Sitinjak, J. R., Tumpal, dan Sugiarto. (2006). Lisrel. Cetakan Pertama. Yogyakarta: Graha Ilmu.

Sugiyono. (2007), Statistika Penelitian Bisnis. Cetakan Kesebelas. Jakarta: Alfabeta.

Supratikno, H. (2007). Peran swasta dalam paradigma baru ekonomi; sidang Pleno XII ISEI Bandung 19-20 juli 2007.

Suryana. (2003). Kewirausahaan. Jakarta: Salemba Empat.

Sugiyono. (2005). Memahami Penelitian Kualitatif. Bandung: Alfabeta.

Tjiptono, F. (2002). Strategi Pemasaran. Yogyakarta: ANDI.

Turban, E. (2004a.). Electronic Commerce: A Managerial Perspective. New Jersey: Prentice Hall.

Turban (2004b), Information technology for management $4^{\text {th }}$ edition. John Wiley \& Sons.

Turban, E., King, D: Lee Jae: Vichland, Dennis (2002). Electronic Commerce: a managerial perspective 2002 (International edition ). New Jersey: Pearson Prentice Hall.

Turban, Rainer, Potter. (2003). Introduction to Information Technology, 2nd Edition. USA: John Wiley \& Sons.

Umar, Musni, Dahlan, M. (2002). Terobosan Pemulihan Ekonomi Indonesia. Jakarta: Forum Kampus Kuning.

Vincent Gazpersz.(2003). Metode Analisis untuk Peningkatan Kualitas. PT. Gramedia Pustaka Utama. Jakarta.

Vincent Gazpersz.(2003). Total Quality Management. PT. Gramedia Pustaka Utama. Jakarta.

Widjojo, Prasetijono, (2010) Peran UMKM sebagai penggerak Transformasi Struktural dan Pertumbuhan Ekonomi Berkelanjutan; Sidang Pleno ISEI XIV Bandung, 20 Juli 2010.

Warouw, Adolf, (2007) Membangun daya saing Sektor jasa; sidang pleno XII, Balikpapan, 19-20 Juli 2007.

Wilkinson, J. And Sykes, L, 2010, A guide to Succession: Sustaining families and farms. Australian Government, Grains Research and Development Corporation.

Wijanto, S. H. (2008). Structural Equation Modeling dengan Lisrel 8.8. Yogyakarta: Graha Ilmu.

Yatini, I. B. (2007). Interaksi Manusia dan Komputer. Yogyakarta: Graha Ilmu.

Zimmerer, W. T., dan Scarborough, N. M. (2004). Pengantar Kewirausahaan dan Manajemen Bisnis Kecil. Jakarta: Indeks.

http://infoukm.wordpress.com/2008/08/11/keragaman-definisi-ukm-di-indonesia/

http://www.paketrupiah.com/artikel/batik,_budaya_jawa_kelas_dunia.php, Januari 2011

http://mybusinessblogging.com/entrepreneur/2009/07/16/batik-jawa-tengah-menggeliat/ januari 2011 
http://eprints.undip.ac.id/1570/ januari 2011

http://www.membuatblog.web.id/2010/02/sejarah-batik.html., Januari 2011

http://batikdamayanti.com/batik-news/sejarah-batik-indonesia.html, januari 2011

http://www.unesco.or.id/media/Culture_and_Communication_2009.pdf, januari 2011

http://www.tdwclub.com/berita/sejarah-perkembangan-batik-dan-batik-di-indonesia/, januari 2011

http://pasar-klewer.com/index.php?option=com_content\&task=view\&id=2\&Itemid=13, januari 2011

http://pasar-klewer.com/index.php?option=com_content\&task=blogsection\&id=3\&Itemid=14, januari 2011

http://www.surakarta.go.id/id/news/kampung.batik.html, januari 2011

http://dgi-indonesia.com/garis-waktu-batik-indonesia/, januari 2011 


\section{LAMPIRAN}

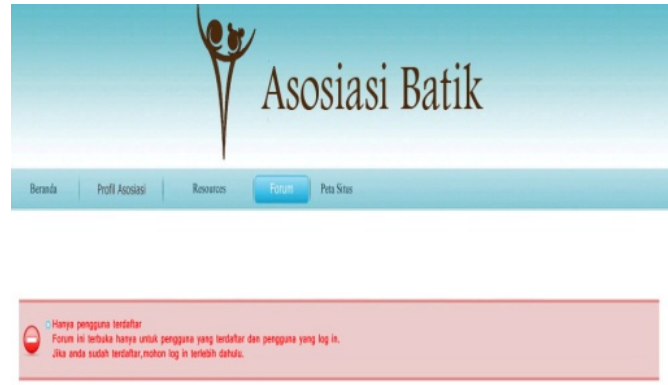

Gambar 4 Tampilan Forum

(Sumber: Penulis, 2012)

Asosiasi Batik

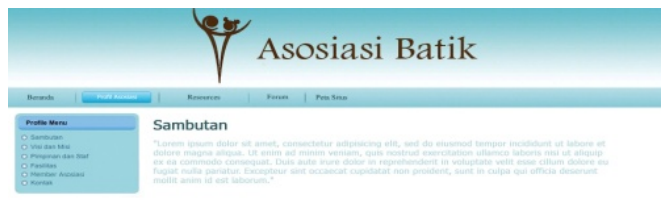

Gambar 6 Tampilan Sambutan

(Sumber: Penulis, 2012)

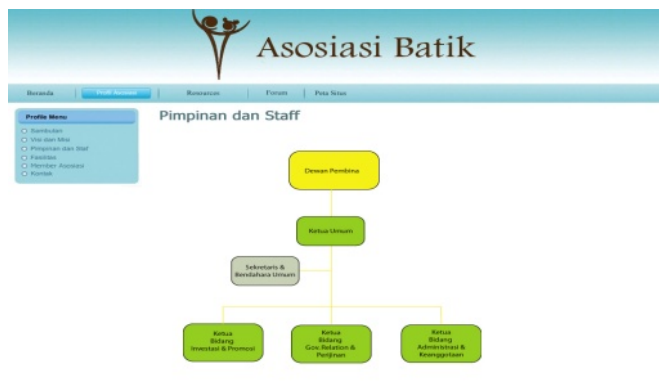

Gambar 8 Tampilan Pimpinan dan Staf

(Sumber: Penulis, 2012)

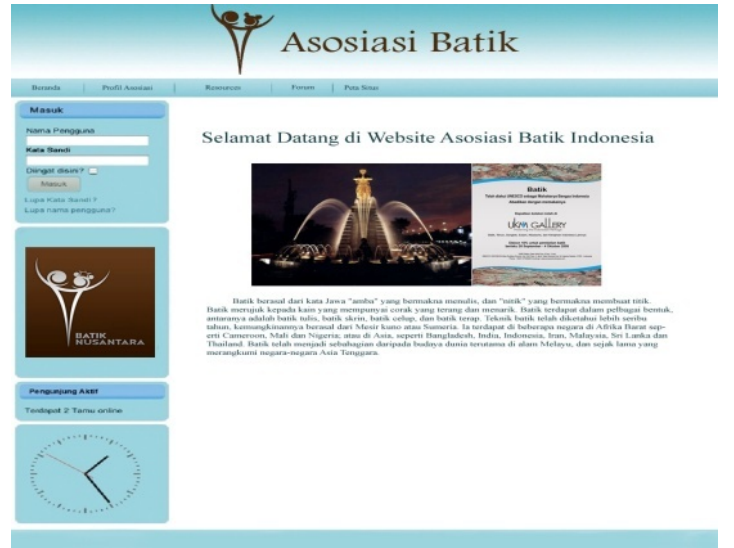

Gambar 5 Tampilan Beranda (Sumber: Penulis, 2012)
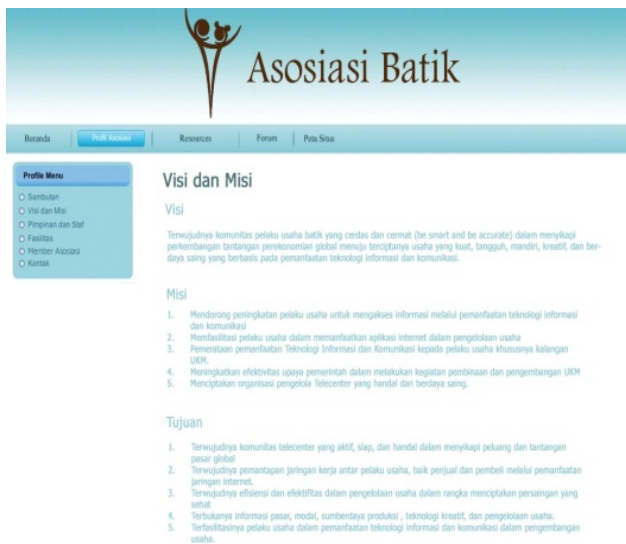

Gambar 7 Tampilan visi dan misi Asosiasi (Sumber: Penulis, 2012)

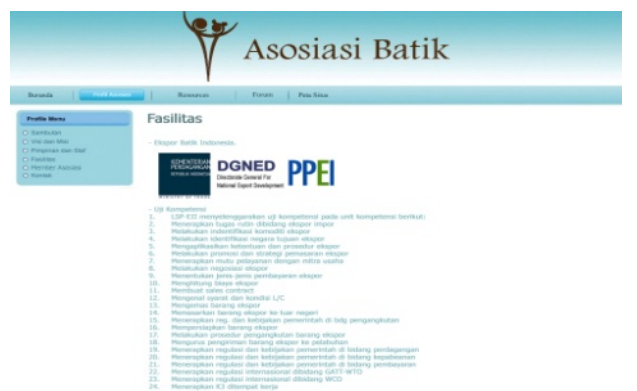

Gambar 9 Tampilan Fasilitas (Sumber: Penulis, 2012) 


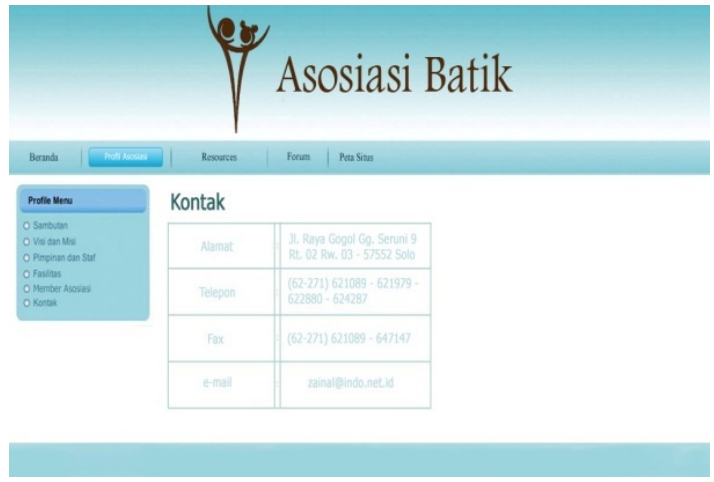

Gambar 10 Tampilan Anggota Asosiasi

(Sumber: Penulis, 2012)

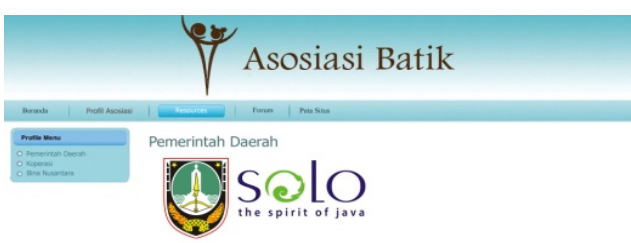

Gambar 12 Tampilan Pemda

(Sumber: Penulis, 2012)

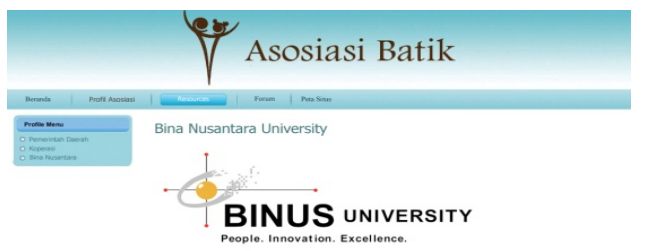

Gambar 14 Tampilan Perguruan Tinggi (Sumber: Penulis, 2012)

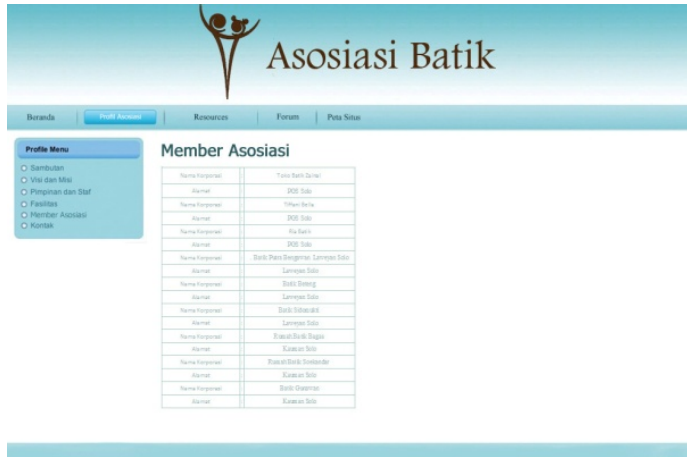

Gambar 11 Tampilan Kontak (Sumber: Penulis, 2012)

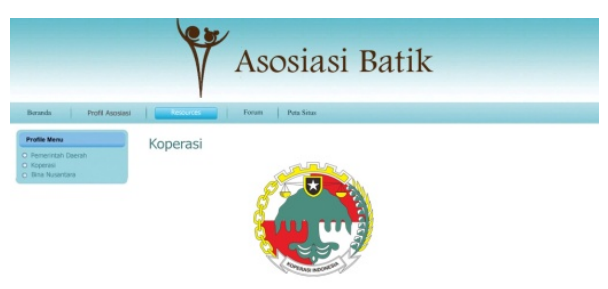

Gambar 13 Tampilan Koperasi (Sumber: Penulis, 2012)

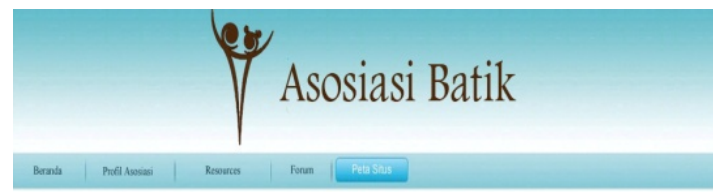

Peta Situs

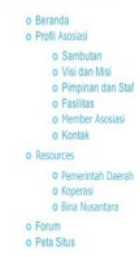

Gambar 15 Tampilan Peta Situs

(Sumber: Penulis, 2012) 


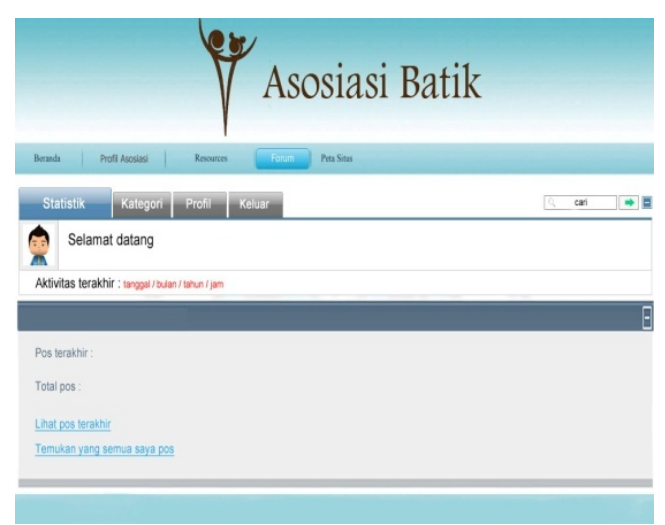

Gambar 16 Tampilan setelah login (Sumber: Penulis, 2012)

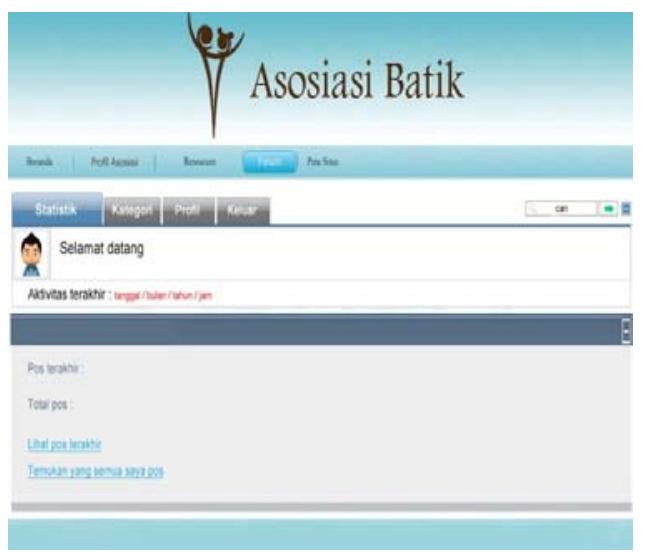

Gambar 18 Tampilan Forum Kategori (Sumber: Penulis, 2012)

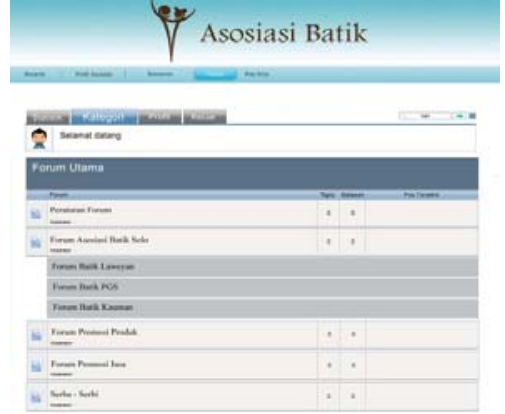

Gambar 17 Tampilan Forum Statistik (Sumber: Penulis, 2012)

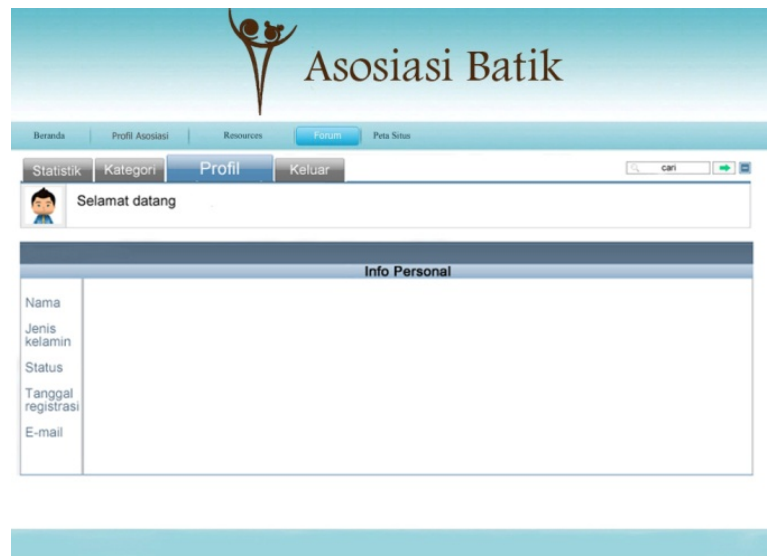

Gambar 19 Tampilan Profil User

(Sumber: Penulis, 2012) 